\title{
Pengaruh ukuran perusahaan, kualitas audit dan profitabilitas terhadap ketepatan penyampaian laporan keuangan
}

\author{
Fitri Dwi Jayanti* \\ * Fakultas Ekonomika dan Bisnis, Universitas Selamat Sri Kendal, fitridj@ gmail.com, Kendal, Indonesia
}

\author{
ARTICLE INFO \\ Article history: \\ Received 01 Maret 2018 \\ Received I Revised 25 Juli \\ 2018 \\ Accepted 30 Juli 2018 \\ Keywords: \\ Company Size, \\ Quality of $K A P$, \\ Profitability, the \\ accuracy of financial \\ statement submission.
}

A B S T R A C T

This research aimed to examine the influence of the which consists company size, audit quality and profitability on the accuracy of financial statement submission in the manufacturing companies listed on the Indonesia Stock Excange (IDX) in 2013 to 2015. Purposive sampling technique is used to obtain the sample size by 66 manufacturing or 198 data in three years. To analyze hyphotesis this research used logistic regression with SPSS version 21. The result of this study showed that audit quality variabels measured by Public Accountant Office big four and non big four received or influenced the accuracy of financial statement submission while the variable size of the company and profitability hypothesis rejected or variable does not affect the accuracy of financial statement submission.

Penelitian ini bertujuan untuk menguji pengaruh yang terdiri dari ukuran perusahaan, kualitas audit dan profitabilitas terhadap ketepatan penyampaian laporan keuangan pada perusahaan manufaktur yang terdaftar di Bursa Efek Indonesia (BEI) pada tahun 2013 hingga 2015. Teknik purposive sampling digunakan untuk memperoleh ukuran sampel sebanyak 66 manufaktur atau 198 data dalam tiga tahun. Untuk menganalisa hipotesa penelitian ini menggunakan regresi logistik dengan SPSS versi 21. Hasil penelitian ini menunjukkan bahwa variabel kualitas audit yang diukur oleh empat besar Kantor Akuntan Publik dan non empat besar mampu menerima atau mempengaruhi ketepatan penyampaian pengajuan laporan keuangan sedangkan hipotesis mengenai variabel ukuran perusahaan dan profitabilitas ditolak atau variabel tersebut tidak mempengaruhi ketepatan penyampaian pengajuan laporan keuangan. 
Perusahaan atau pihak manajemen wajib melaporkan kondisi keuangan perusahaan melalui laporan keuangan. Keandalan dalam penyampaian informasi laporan keuangan sangat diharapkan oleh pihak-pihak pemakai laporan keuangan, seperti investor dan kreditor dalam pengambilan keputusan. Perusahaan yang Go Public wajib melaporkan laporan keuangan yang sudah diaudit oleh auditor selambat-lambatnya pada akhir bulan ketiga setelah tanggal laporan keuangan tahunan berdasarkan Keputusan Keu Badan Pengawas Pasar Modal dan Lembaga Keuangan Nomor : KEP-346/BL/2011 tentang penyampaian laporan keuangan berkala emiten atau perusahaan publik, yang saat ini Badan Pengawas Pasar Modal dan Lembaga Keuangan diambil alih oleh Otoritas Jasa Keuangan (OJK).

Ketepatan waktu pelaporan keuangan sangatlah dibutuhkan oleh pihak internal dan eksternal perusahaan (manajemen perusahaan, investor, calon investor, karyawan, pemerintah, dan kreditor). Penyampaian laporan keuangan secara tepat waktu akan mengurangi asimetri informasi antara manajemen dan pemilik perusahaan. Pihak investor atau stakeholder menginginkan laporan keuangan diumumkan secara tepat waktu dan akurat, adanya keterlambatan dalam penyampaian laporan keuangan akan menyebabkan menurunnya tingkat kepercayaan investor dalam pengambilan keputusan dan akan berakibat pada reaksi pasar modal. Dyer, J.C. dan McHugh (1975) mengungkapkan bahwa untuk menghasilkan laporan keuangan yang memadai harus memperhatikan ketepatwaktuan dalam publikasi laporan keuangan. Pelaporan keuangan yang tepat pada waktunya akan menghasilkan informasi keuangan yang relevan (Abdelsalam dan Street, 2007).

Keterlambatan pelaporan keuangan merupakan pertanda buruk bagi kondisi kesehatan perusahaan. Pada umumnya, investor menganggap perusahaan dengan kondisi kesehatan yang buruk biasanya cenderung melakukan kesalahan manajemen. Tingkat laba dan keberlangsungan hidup perusahaan yang terganggu, akan memerlukan tingkat ketelitian dan kecermatan pada saat pengauditanya. Ketepatan waktu penyampaian laporan keuangan perusahaan tergantung dari ketepatan waktu auditor dalam menyelesaikan tugas auditnya. Audit delay adalah waktu penundaan pelaporan laporan keuangan perusahaan yang diukur dari tanggal tutup buku laporan keuangan perusahaan hingga dipublikasikan di Bursa Efek Indonesia (BEI), Kusumawardani (2013).

Puspitasari dan Sari (2012) mengungkapkan bahwa ukuran perusahaan yang diukur dengan total asset mempunyai pengaruh positif dan signifikan terhadap audit delay, solvabilitas mempunyai pengaruh positif dan signifikan terhadap audit delay, laba/rugi perusahaan mempunyai pengaruh negatif dan signifikan terhadap audit delay, dan ukuran KAP mempunyai pengaruh negatif dan signifikan terhadap audit delay. Nasution (2013) mengungkapkan bahwa likuiditas dan profitabilitas berpengaruh signifikan positif terhadap ketepatan waktu dalam pelaporan keuangan. Sedangkan ukuran perusahaan berpengaruh signifikan negatif terhadap ketepatan waktu dalam pelaporan keuangan.

Terdapat ketidak-konsistenan hasil penelitian terdahulu sehingga perlu dilakukan penelitian lebih lanjut untuk mengeneralisasi hasil penelitian. Dalam penelitian ini kualitas audit ditambahkan sebagai variable pembeda. Penelitian ini bertujuan untuk menguji pengaruh ukuran perusahaan, kualitas audit dan profitabilitas terhadap ketepatan penyampaian laporan keuangan. 


\section{METODE}

\subsection{Populasi dan Sampel}

Populasi dalam penelitian ini adalah perusahaan manufaktur yang terdaftar di Bursa Efek Indonesia (BEI) pada tahun 2013, 2014, 2015 dengan menggunakan teknik purposive sampling. Berdasarkan teknik purposive sampling yang telah dilakukan terdapat 92 perusahaan yang masuk didalam kriteria sampel. Setelah melakukan pengujian terdapat 26 perusahaan yang harus dihilangkan atau dioutlier. Sehingga total sampel perusahaan dalam penelitian ini adalah sebanyak 66 perusahaan atau 198 data selama tiga tahun.

\subsection{Definisi Operasional Variabel}

\section{a. Variabel Dependen}

Variabel dependen dalam penelitian ini adalah ketepatan waktu dalam penyampaian laporan keuangan. Ketepatan penyampaian laporan keuangan adalah rentang waktu antara tanggal laporan keuangan perusahaan ditutup yaitu pada tanggal 31 desember hingga tanggal ketika auditor selesai melakukan proses audit yang tercantum di tanggal tandatangan oleh auditor eksternal, yang berarti semakin cepat auditor menandatangani laporan keuanagan maka semakin cepat laporan keuangan disampaikan. Lampiran Keputusan Ketua Bapepam No : Kep-346/BL/2011 menyatakan bahwa perusahaan yang menyampaikan laporan keuangan selambat-lambatnya pada tanggal 31 maret atau 90 hari sejak tutup buku, yang berarti perusahaan yang terlambat yaitu perusahaan yang menyampaikan laporan keuangannya setelah tanggal 31 Maret.

\section{b. Variabel Independen}

\section{Ukuran Perusahaan}

Ukuran perusahaan merupakan nilai yang menunjukkan besar kecilnya suatu perusahaan (Anggradewi dan Haryanto, 2014). Variabel ukuran perusahaan diukur dengan menggunakan total asset yang diproksikan dengan menggunakan logaritma.

\section{Kualitas Audit}

Kualitas Audit diukur dengan menggunakan kualitas Kantor Akuntan Publik (KAP) yang diukur dengan menggunakan variabel dummy. Kategori jasa yang menggunakan Kantor Akuntan Publik (KAP) yang berafiliasi dengan Kantor Akuntan Publik (KAP) Big Four diberi nilai dummy 1 dan kategori perusahaan yang menggunakan jasa Non Big Four diberi nilai dummy 0. 


\section{Rasio Profiabilitas}

ROA (Return on Asset) adalah rasio yang diperoleh dengan membagi laba bersih setelah pajak dengan total aset. Rasio ini menggambarkan kemampuan perusahaan mendapatkan laba melalui semua kemampuan, dan sumber yang ada seperti kegiatan penjualan, kas, modal, jumlah karyawan, junlah cabang, dan sebagainya (Harahap, 2008).

\section{Return on Asset $\frac{\text { Lababersih setelah pajak }}{\text { total asset }}$}

\subsection{Metode Analisis}

Metode analisis data yang digunakan dalam penelitian ini untuk pengujian hipotesis adalah model analisis regresi linier berganda. Model regresi yang digunakan dalam penelitian ini adalah sebagai berikut :

$$
\mathrm{Y}=\alpha+\beta 1 \mathrm{X} 1+\beta 2 \mathrm{X} 2+\beta 3 \mathrm{X} 3+\mathrm{e} \ldots
$$

Dimana :

Y : Ketepatan Waktu dalam Penyampaian Laporan Keuangan

$\alpha \quad$ : Konstanta

$\beta 1-\beta 3$ : Koefisien Regresi Parsial untuk masing-masing variabel X1, X2, X3

X1 : Ukuran Perusahaan (Size)

X2 : Kualitas Audit (KAP)

X3 : ROA

E : Kesalahan (Faktor Pengganggu)

\subsection{Pengaruh Ukuran Perusahaan terhadap Ketepatan Waktu dalam Penyampaian Laporan Keuangan}

Semakin besar ukuran perusahaan maka audit delay semakin pendek, dalam hal ini perusahaan akan cepat waktu dalam penyampaian laporan keuangannya. Perusahaan dengan skala yang besar cenderung memiliki sumber daya manusia, sistem informasi dan sistem pengendalian internal yang baik. Hal ini akan berpengaruh terhadap cepatnya penyelesaian laporan keuangan yang akan membantu aduitor dalam proses audit. Perusahaan berskala besar akan lebih tepat waktu dalam penyampaian laporan keuangan untuk menjaga citra perusahaan dimata publik.

Manajemen dengan skala besar cenderung mempercepat penerbitan laporan keuangan auditan karena perusahaan berskala besar dimonitor secara ketat oleh investor, pengawas permodalan dan pemerintah sehingga cenderung menghadapi tekanan eksternal yang lebih tinggi untuk mengumumkan laporan keuangan auditan lebih awal. keuangan.

$\mathrm{H}_{1}$ : Ukuran perusahaan berpengaruh terhadap ketepatan waktu dalam penyampaian laporan 


\subsection{Pengaruh Kualitas Audit terhadap Ketepatan Waktu dalam Penyampaian Laporan Keuangan}

Kantor Akuntan Publik (KAP) yang besar akan selalu menjaga reputasinya dengan tingkat kualitas audit. Sumber daya manusia yang profesional dapat dengan mudah menyelesaikan proses audit. Waktu audit yang cepat merupakan salah satu cara KAP dengan kualitas yang tinggi untuk mempertahankan reputasi mereka.

$\mathrm{H}_{2}$ : Kualitas audit berpengaruh terhadap ketepatan waktu dalam penyampaian laporan keuangan.

\subsection{Pengaruh Profitabilitas terhadap Ketepatan Waktu dalam Penyampaian Laporan Keuangan}

Perusahaan dikatakan berhasil jika memperoleh keuntungan atau laba yang tinggi. Perusahaan ingin segera mempublikasikan tingkat profitabilitas yang tinggi kepada para pemakai laporan keuangan. Perusahaan tidak akan menunda penyampaian informasi ini. Perusahaan yang memiliki tingkat profitabilitas yang lebih tinggi akan cepat waktu dalam menyampaikan laporan keuangan dikarenakan keharusan untuk segera menyampaikan kabar baik kepada publik.

Auditor akan lebih berhati-hati dan lebih fokus dalam menghadapi perusahaan yang mengalami kerugian. Jika perusahaan menghasilkan tingkat profitabilitas yang tinggi maka audit delay akan lebih pendek dibandingkan dengan perusahaan dengan tingkat profitabilitas yang lebih rendah.

$\mathrm{H}_{3}$ : Profitabilitas berpengaruh terhadap ketepatan waktu dalam penyampaian laporan keuangan.

\section{Kerangka Pemikiran}

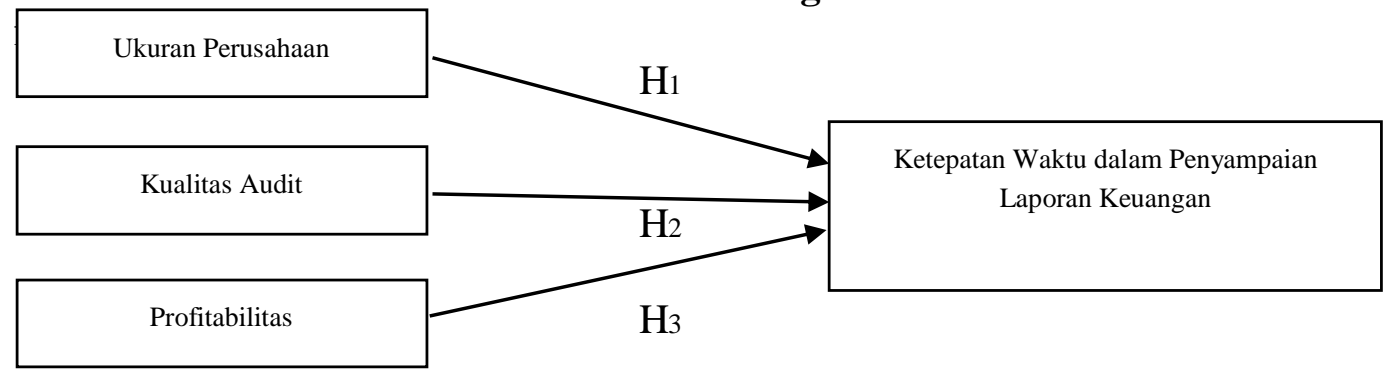

\section{Gambar 1}

\section{HASIL DAN PEMBAHASAN}

\subsection{Pengujian Hipotesis}

Hasil pengujian hipotesis pada tabel 1 dengan menggunakan uji t-Test yang dilakukan untuk menguji pengaruh dari masing-masing variabel independen (ukuran perusahaan, kualitas audit yang diukur dengan KAP dan profitabilitas yang diukur dengan ROA terhadap variabel dependen (ketepatan waktu dalam penyampaian laporan keuangan). Apabila nilai sig $\mathrm{t}<$ tingkat signifikansi (0.05) maka hipotesis diterima, sedangkan apabila nilai sig t > tingkat signifikansi (0.05) maka hipotesis ditolak. Berikut hasil uji hipotesis dengan menggunakan uji t-Test: 


\section{Tabel 1}

\section{Hasil Uji t-Test}

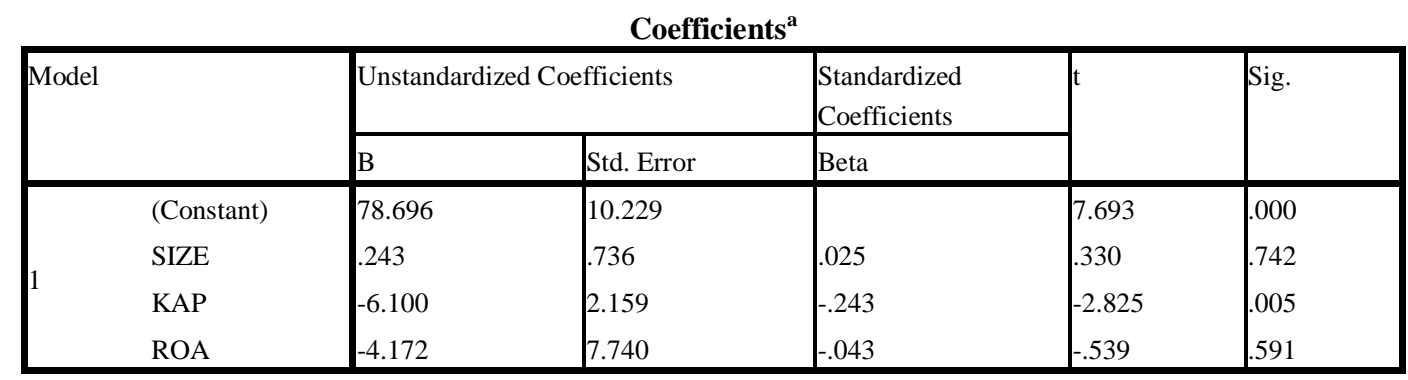

a. Dependent Variable: KEC

Sumber : Data yang diolah, tahun 2017

Hasil pengujian hipotesis tersebut menghasilkan persamaan analisis regresi berganda berikut ini :

$$
\mathrm{Kec}=78.696+0.243 \mathrm{X} 1-6.100 \mathrm{X} 2-4.172 \mathrm{X} 3+\mathrm{e}
$$

Hipotesis kesatu menguji pengaruh ukuran perusahaan terhadap ketepatan waktu dalam penyampaian laporan keuangan. Berdasarkan hasil pada tabel 1 di atas diperoleh nilai sig 0.742>0.05, yang berarti bahwa hipotesis kesatu dinyatakan ditolak. Ukuran perusahaan yang besar belum tentu menjamin ketepatan waktu dalam menyampaian laporan keuangannya. Auditor juga menganggap bahwa dalam proses pengauditan berapapun jumlah total aset yang dimiliki perusahaan akan diperiksa dengan cara yang sama sesuai dengan standar dan prosedur dalam Standar Profesional Akuntan Publik (SPAP). Hal ini konsisten dengan hasil penelitian Anggradewi dan Haryanto (2014), Saemargani dan Mustikawati (2015)

Hipotesis kedua menguji pengaruh kualitas KAP terhadap ketepatan waktu dalam penyampaian laporan keuangan. Berdasarkan hasil pada tabel 1 di atas diperoleh nilai sig $0.005<0.05$, yang berarti bahwa hipotesis kedua dinyatakan diterima. Hasil penelitian hipotesis kedua membuktikan bahwa kualitas audit berpengaruh terhadap ketepatan waktu dalam penyampaian laporan keuangan, KAP besar cenderung lebih cepat menyelesaikan tugas audit dibandingkan dengan KAP non big four. Hal ini konsisten dengan penelitian Candraningtyas, dkk (2017) tetapi tidak konsisten dengan hasil penelitian Saemargani dan Mustikawati (2015), Muhammad dan Suzan (2016) yang menyatakan bahwa kualitas audit tidak mempunyai pengaruh terhadap audit delay.

Hipotesis ketiga menguji pengaruh profitabilitas yang diukur dengan ROA terhadap ketepatan waktu dalam penyampaian laporan keuangan. Berdasarkan hasil pada tabel 1 di atas diperoleh nilai sig $0.591>0.05$, yang berarti bahwa hipotesis ketiga dinyatakan ditolak. Kemampuan perusahaan untuk memperoleh laba berdasarkan aktiva tidak berpengaruh terhadap ketepatan waktu penyelesaian audit, pada penelitian ini kemungkinan bahwa perusahaan sampel lebih memprioritaskan hal lain sehingga tidak segera menyampaikan laporan keuangan yang telah diaudit. Hal ini bertolak belakang dengan hasil penelitian yang dilakukan oleh Saemargani dan Mustikawati (2015), Murti dan Widhiyani (2016). 


\section{KESIMPULAN}

Hasil penelitian ini membuktikan bahwa ukuran perusahaan dan profitabilitas tidak berpengaruh signifikan terhadap ketepatan waktu penyampaian laporan keuangan, sedangkan factor kualitas audit menjadi penentu dalam ketepatan penyampaian keuangan. Hal ini karena KAP besar cenderung lebih cepat menyelesaikan tugas audit dibandingkan dengan KAP non big four.

Bagi peneliti selanjutnya, bisa mengembangkan variabel lebih banyak dalam mengetahui faktor ketepatan waktu penyampaian laporan keuangan. Peneliti selanjutnya dapat menggunakan berbagai kelompok perusahaan lain yang selama ini belum pernah dijadikan populasi atau sampel dalam penelitian..

\section{DAFTAR PUSTAKA}

Abdelsalam, O.H., andD. L. Street. 2007. "Corporate governance and the timeliness of corporate internet reporting by U.K. listed companies". Journal of International Accounting, Auditing and Taxation.

Anggradewi, Annurrizky Muflisha dan Haryanto. 2014. Analisis Faktor-Faktor yang mempengaruhi Audit Delay. Diponegoro Journal of Accounting Volume 3, Nomor 2. ISSN : 2337-3806.

Arens, Alvin a., dan Beasly. 2008. Auditing dan Jasa Assurance Pendekatan Terintegrasi Jilid 1. Edisi 12. Jakarta : Erlangga

Cahyanti, Dyna Nuzul, Nengah Sudjana dan Devi Farah Azizah. 2016. Pengaruh Ukuran Perusahaan, Profitabilitas, dan Solvabilitas terhadap Audit Delay. Jurnal Administrasi Bisnis (JAB). Vol.38 No.1

Candraningtyas, Elia Galuh, Ni Luh Gede Erni Sulindawati, dan Made Arie Wahyuni. 2017. Pengaruh Ukuran Perusahaan, Profitabilitas, Solvabilitas, dan Ukuran Kantor Akuntan Publik Terhadap Audit Delay. Jurnal Akuntansi Program S1. Vol : 8 No.2

Dyer, J.C and McHugh Arthur J (1975). Journal of Accounting Research, Vol. 13, No. 2 (Autumn, 1975), pp. 204-219

Ghozali, Imam. 2013. Aplikasi Analisis Multivariate dengan Program IBM SPSS 21. Semarang : Badan Penerbit Universitas Diponegoro.

Harahap, Sofyan Syafri. 2008. Analisis Kritis Atas Laporan Keuagan. Raja Grafindo Persada, Jakarta.

Jensen \& Meckling, 1976, The Theory of The Firm: Manajerial Behaviour, Agency Cost, and Ownership Structure, Journal of Financial and Economics, 3:305-360

Kementrian Keuangan Repubik Indonesia. BAPEPAM. 2011. Nomor :Kep-346/BL/2011

Kim, Oliver., and Robert E., Verrechia, 1994. Market Liquidity and Volume Around Earning Announcement. Journal of Accounting and Economics. Pp. 41-67

Kusumawardani, fitria (2013) Faktor-faktor yang mempengaruhi audit delay pada perusahaan manufaktur. Accounting Anaysis Journal 2 (1). ISSN 2252-6765.

Muhammad, Fadhel dan Suzan, Leny. 2016. Pengaruh Ukuran Perusahaan, Opini Auditor dan Kualitas Kantor Akuntan Publik terhadap Audit Delay. E-Proceeding of Management : Vol.3, No.2 Agustus 2016. ISSN : 2355-9357

Murti, Ni Made Dwi Ari dan Widhiyani, Ni Luh Sari. 2016. Pengaruh Ukuran Perusahaan dan Profitabilitas Pada Audit Delay dengan Reputasi KAP sebagai Variabel Pemoderasi. 2016. EJurnal Akuntansi Universitas Udayana. Vol. 16. ISSN : 2302-8556. 
Nasution, K.A. (2013). Pengaruh Likuiditas, Ukuran Perusahaan Dan Profitabilitas Terhadap Ketepatan Waktu Dalam Pelaporan Keuangan. Jurnal Bisnis dan Ekonomi (JBE), 16 (1) . 1-24.

Puspitasari, E., \& Sari, A. N. (2012). Pengaruh Karakteristik Perusahaan Terhadap Lamanya Waktu Penyelesaian Audit (Audit Delay) Pada Perusahaan Manufaktur Yang Terdaftar Di Bursa Efek Indonesia. Jurnal Akuntansi \& Auditing, 9 (1).

Saemargani, Fitria Ingga dan Mustikawati, Rr. Indah. 2015. Pengaruh Ukuran Perusahaan, Umur Perusahaan, Profitabilitas, Solvabilitas, Ukuran KAP, dan Opini Auditor Terhadap Audit Delay. Jurnal Nominal Vol.4 No.2

www.idx.co.id 